\title{
Complex Tectonic History of Al-Yutamah Dome Area within Hijaz Terrane, Arabian Shield, South of Al Madinah, Saudi Arabia
}

\author{
Abdullah O. Bamousa* \\ Geology Dept, Faculty of Sciences, Taibah University, P.O. Box 30002, Al Madinah 41477, Saudi Arabia
}

\begin{abstract}
This paper documents the Al-Yutamah tectonic dome, located in the northwestern part of the Arabian Shield, Saudi Arabia. A new Infracambrian over-thrust fault zone is mapped, which superpose the Late Proterozoic rocks in the area. Kinematic indicators suggest top-to-the-south movements along this fault, mainly compressional and some extensional in nature. The area experienced several tectonic events that resulted in to a complex dome like structure formation with a surface area of $20 \times 50 \mathrm{~km}^{2}$. The $S_{1}$ cleavages, which have been determined as the oldest structural features in the area, are attributed to $\left(\mathrm{D}_{1}\right)$ tectonic event along the Labunah Thrust Fault. This event was followed by another deformational event $\left(D_{2}\right)$ that produced N-S trending $F_{2}$ folds in the area. The third deformational event $\left(D_{3}\right)$ observed in the area is the brittle high-angle reverse faults, which generally dip toward north and south, suggesting compressional nature of the event. Fourth deformational event $\left(\mathrm{D}_{4}\right)$ in the area resulted in the formation of E-W trending $\mathrm{F}_{4}$ folding, which occurred subsequent to the development of Najd Strike-slip Faulting and $\mathrm{F}_{2}$ folding. Superposition of the $\mathrm{F}_{2}$ and $\mathrm{F}_{4}$ folds in the area developed a complex structural feature in the shape of Al-Yutamah dome. Overthrusting of the meta-sedimentary rocks as a result of movement along the Al-Yutamah fault is considered as a fifth tectonic event $\left(D_{5}\right)$. The Al-Yutamah over-thrust fault is most likely late Infracambrian in age, which is associated with the Najd Strikeslip Fault zone. The Cenozoic listric faulting that probably exhumed the dome is considered as a sixth deformational event $\left(D_{6}\right)$ in the area. During the Cenozoic, cross-cut faults developed in the dome by high-angle normal faulting that dissected it into different segments.
\end{abstract}

Keywords: Al-Yutamah Dome, superposed folds, Labunah Thrust Fault, Al Madinah.

\section{INTRODUCTION}

Although, the Neoproterozoic (900 - $550 \mathrm{Ma})$ Arabian Shield is considered as a juvenile shield [1], it underwent several phases of subduction, amalgamation and postamalgamation tectonic events, which resulted in to a reworked complex continental lithosphere of the heterogeneous terranes [2-8]. Amalgamation of these terranes formed the Arabian Shield by accretion and juxtaposition of the oceanic slivers. Slivers are mainly ophiolitic in nature, which occur within the arc-arc suture zone [9]. Post-amalgamation deposition, accompanied by extension, was followed by collision tectonics [2, 8]. All these tectonic events are in one way or another linked to different grades of metamorphism and plutonic emplacement.

The Arabian Shield has been divided into western and eastern parts [1]. The western part (oceanic crust affinity) extends over the Red Sea to African continent, and is made of four terranes. From north to south, they are Midyan, Hijaz, Jeddah and Asir terranes. On the other hand, eastern part of the Arabian Shield is believed to have mainly continental crust affinity, which consists of Khida, Afif, ArRayn, Ad-Dawadimi and Hail terranes.

*Address correspondence to this author at the Geology Dept, Faculty of Sciences, Taibah University, P.O. Box 30002, Al Madinah 41477, Saudi Arabia; Tel: +96648460008, Ext. 1432; Fax: +96648454770;

E-mail: abamousa@taibahu.edu.sa
The Thurwah-Bir Umq Suture (TBUS) zone, which separate Hijaz terrane from Jeddah terrane in the western part, extends up to $300 \mathrm{~km}$ towards northeast from Rabigh Town, via the Red Sea coast, to Bir Umq area. This suture zone has been named as Labunah Thrust Fault in the 1:250,000 geological maps of Rabigh and Umm Al-Birak $[10,11]$. The TBUS zone contains NE-SW trending thrust faults, verging toward south and southeast. This suture zone, which evolved during the 783-764 Ma interval [1], is located at about $100 \mathrm{~km}$ south of the study area. Based on other assumptions, formation of the TBUS has been linked to collisions between intra-oceanic island arc and back arc terranes between 800 and $700 \mathrm{Ma}$ [12-15]. In addition, they are considered as E-NE trending arc-arc sutures due to their association with ophiolite slivers (Fig. 1). The deformation occurred in the interval between 783 and $764 \mathrm{Ma}$ is considered as one of the oldest tectonic events that affected the Arabian Shield.

The Najd Fault System (NFS), which is a NW-SE trending left lateral (wrench) strike-slip fault, is one of the structural features in the region that postdate the East African Orogeny (EAO) or the Pan African Orogeny $[9,15]$. The EAO took place between 670 and $610 \mathrm{Ma}$ as a result of collision between the east and west Gondwanaland [9, 15 and 16]. However, activities along the NFS occurred between 620 and $540 \mathrm{Ma}$, which significantly affected a part of the Arabian Shield with a total area of 1200-2000 $\times 300$ $\mathrm{km}^{2}$ [17]. Displacements along the NFS vary from 2 to 25 


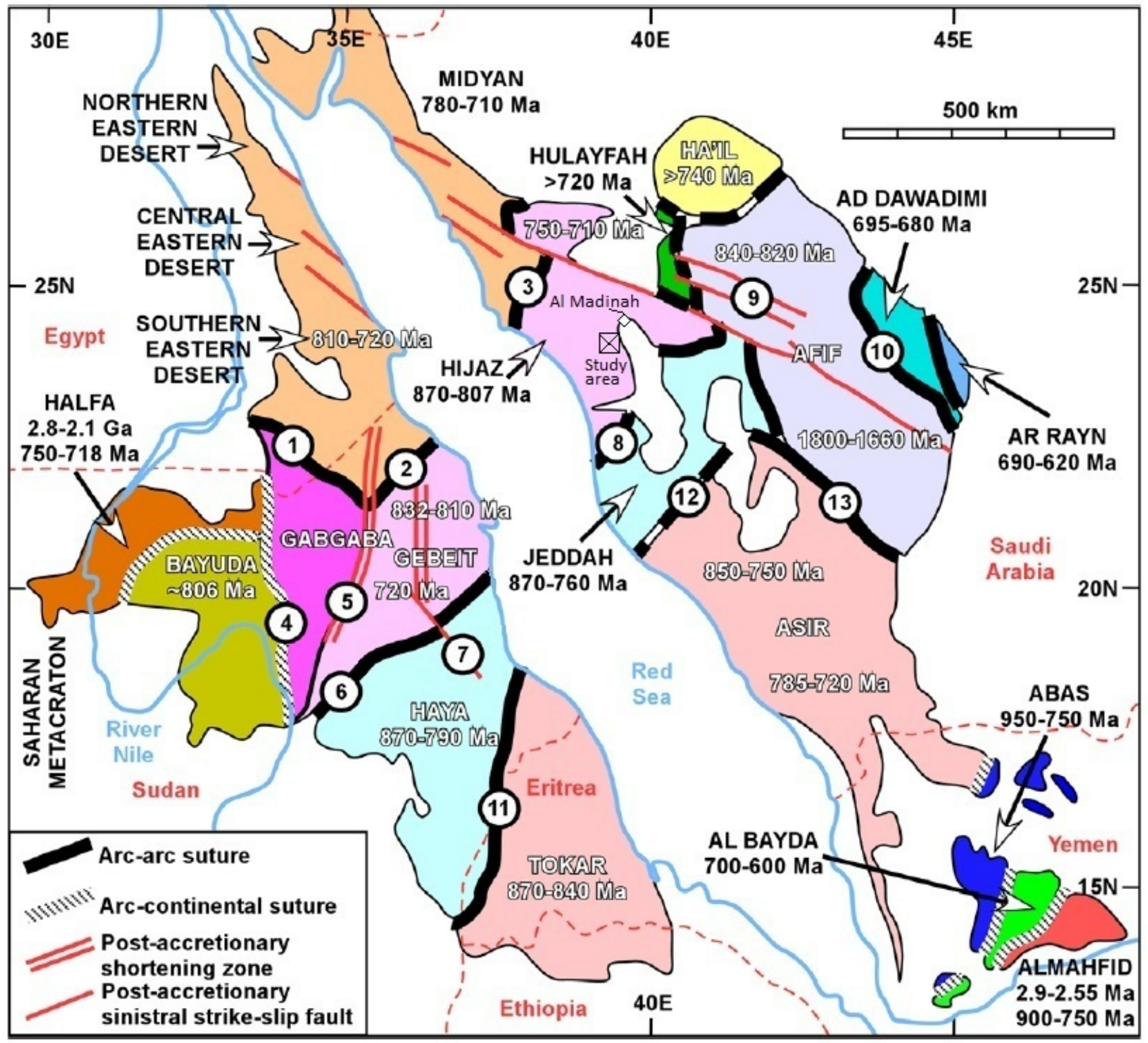

Fig. (1). Tectono-geological map of the Arabian-Nubian Shield terranes [modified after 15]. Location of the study area, south of Al Madinah, is marked on the map. $1=$ Allaqi Suture, $2=$ Sol Hamed Suture, $3=$ Yanbu Suture, $4=$ Keraf Suture, $5=$ Hamisana Shear Zone, $6=$ Nakasib Suture, 7 = Oko Shear Zone, $8=$ Thurwah-Bir Umq Suture, $9=$ Najd Fault System, $10=$ Al Amar Suture, $11=$ Baraka Lineament, $12=$ Afaf Belt and 13 = Hulayfah-Ad Dalinah-Ruwah Fault Zone.

$\mathrm{km}$ and at some places they reach up to $40 \mathrm{~km}[18]$. The NFS is also taken as an instigator for E-W trending folds in the area. Superposition of these folds on N-S trending fold structures caused a dome like structure formation and refolding of the strata in central part of the Arabian Shield [11].

During the Oligocene, western part of the Arabian Shield was affected by continental basaltic eruptions (alkaline) associated with Red Sea opening [19]. The Cenozoic tectonics resulted in to large thermal plume activity below the African Horn [20]. Remanents of this volcanism are mainly present in the Asir Terrane, western part of the Arabian Shield. From mid-Miocene, the western part of the Arabian Shield experienced intermittent intra-plate volcanic eruptions, known as the Harrat Volcanics. These volcanics cover over $900 \mathrm{~km}$ long north-south zone, starting from north Yemen, through Makkah and Madinah to Nafud desert in the north. The northernmost $600 \mathrm{~km}$ long part of this zone is known as the Makkah-Madinah-Nafud (MMN) Volcanic Zone, believed to be the surface manifestations of mantle plume system [21, 23].

This study aims to present new mapping of the overthrust fault zone, which significantly affected the AlYutamah structural Dome in the Arabian Shield. The study further aims to examine the origin of over-thrusting, whether it is related to late Proterozoic east-northeast trending TBUS zone or to Infra-Cambrian north-west trending Najd Fault system. The present study also shed lights on structural development in the Al-Yutamah area as a result of subsequent deformational events. 


\section{GEOLOGY OF THE STUDY AREA}

The rock units exposed in the study area belong to Qahah Formation (Birak Group), which consists of mafic to felsic epiclastic rocks, conglomerate and subordinate volcanics [11]. The Birak Group rocks, which are affected by lowgrade greenschist metamorphism, are overlain by Furayh Group rocks. The Furayh Group rocks were deposited in post-amalgamation basins [3]. The youngest rock unit of ArRayyan Formation (about $1500 \mathrm{~m}$ thick) is exposed in the southernmost part of the study area, which unconformably overly the Furayh Group. This Formation varies in composition from conglomerate-rich beds in the lower part to siltstone and shale in the upper part, with no traces of volcanic rocks [11]. The study area is geologically a part of southern Hijaz Terrane in western Arabian Shield, Saudi Arabia. Geographically, the study area is located in the vicinity of Al-Yutamah town, about $80 \mathrm{~km}$ south of Al-Madinah along the Makkah-Madinah (Hijrah) Highway (Fig. 2).

\section{METHODOLOGY AND RESULTS}

This study was conducted based on two aspects: field investigations and image interpretations. Field investigations were performed along the Hijrah Highway, which was chosen as a main transect due to good rocks exposures. Most of the structural trends are oblique or perpendicular to the path of the road. Image interpretations were performed on Landsat ETM+ remote sensing data. The Landsat imagery is a false color composite image of bands 7, 4, 2 in red, green and blue filters (Fig. 2). In order to get reliable results, several image pre-processing techniques (such as geometric correction) and image enhancements methods (such as histogram stretching) were used for this study. The following sections describe and classify the investigated structural features from older to younger, such as pre-EAO, syn-EAO and post-EAO.

\subsection{Pre- EAO Structures}

\subsubsection{Low Angle $S_{1}$ Cleavages}

In the study area, $S_{1}$ cleavages are nearly flat surfaces and can be seen clearly in greenschist grade metamorphic rocks of the Birak Group for more than $20 \mathrm{~km}$ along the road. They are bounded by Furauh Group rocks from north and south in the core of Al-Yutamah Dome (Fig. 2). An over-thrusting structural feature together with low-grade greenschist metamorphism is observed in the Birak Group rocks of the area. This deformational event is considered as

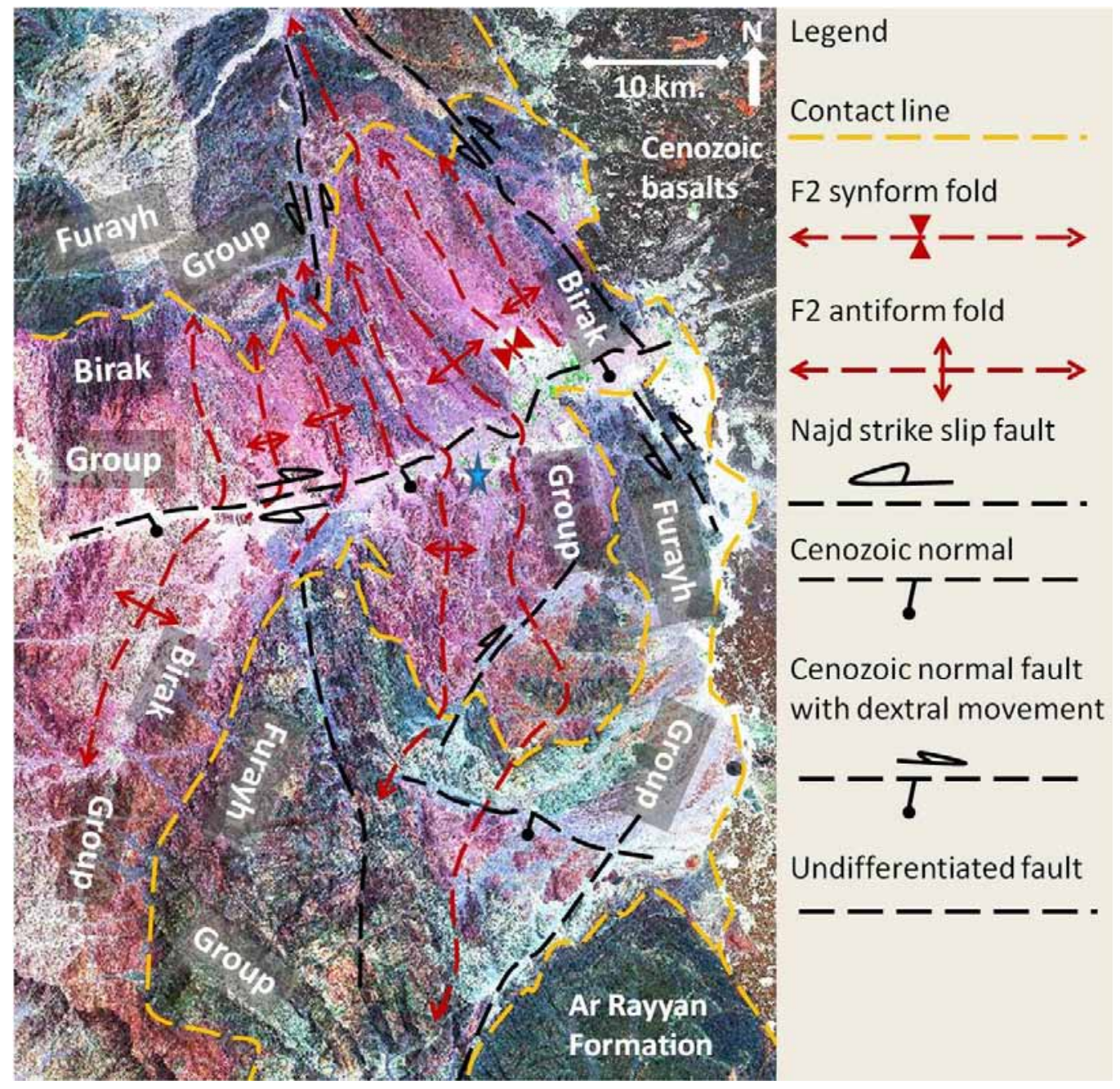

Fig. (2). Geologic map of the study area. This map is drawn using FCC image of 7, 4, and 2 bands in RGB from ETM+ data. Geologic relationships and structural features are taken from [11]. Blue star in the map indicates the Alyutamah town. 
$\mathrm{D}_{1}$, which is probably related to activities along the Labunah Thrust Fault.

\subsection{Syn-EAO Structures}

\subsubsection{Development of $F_{2}$ Folding}

The second deformational event $\left(\mathrm{D}_{2}\right)$ resulted in to $\mathrm{F}_{2}$ folding and $S_{2}$ axial plane cleavages (associated with $F_{2}$ folds). This may be an oldest tectonic event occurred after the deposition of Qahah Formation and the development of $\mathrm{S} 1$ cleavages. The structures developed by this event crosscut the features of $F_{2}$ folding. The $F_{2}$ folding has generally $\mathrm{N}-\mathrm{S}$ trending axial planes, suggesting an E-W directed compressional stresses caused by syn-EAO tectonic event.
The Furayh Group rocks consists of rhyolite tuff and marbleized carbonates (similar to rocks of Ablah Group), which are affected by $F_{2}$ folding [8]. The intersection between $S_{1}$ and $S_{2}$ surfaces has produced pencil-like linear structures that plunge gently towards north. The lineations produced by $S_{1} / S_{2}$ intersection are only observed in the greenschist rocks of Birak Group, but not in the Furayh Group, suggesting that the Furayh Group of rocks were deposited after the development of $\mathrm{S}_{1}$ cleavage development.

\subsubsection{High-Angle Reverse Faults}

Reverse faults in the area mainly trend in E-W direction and dip towards south and north, suggesting two sets of high-angle reverse faults (Fig. 3). These faults have been

(A)

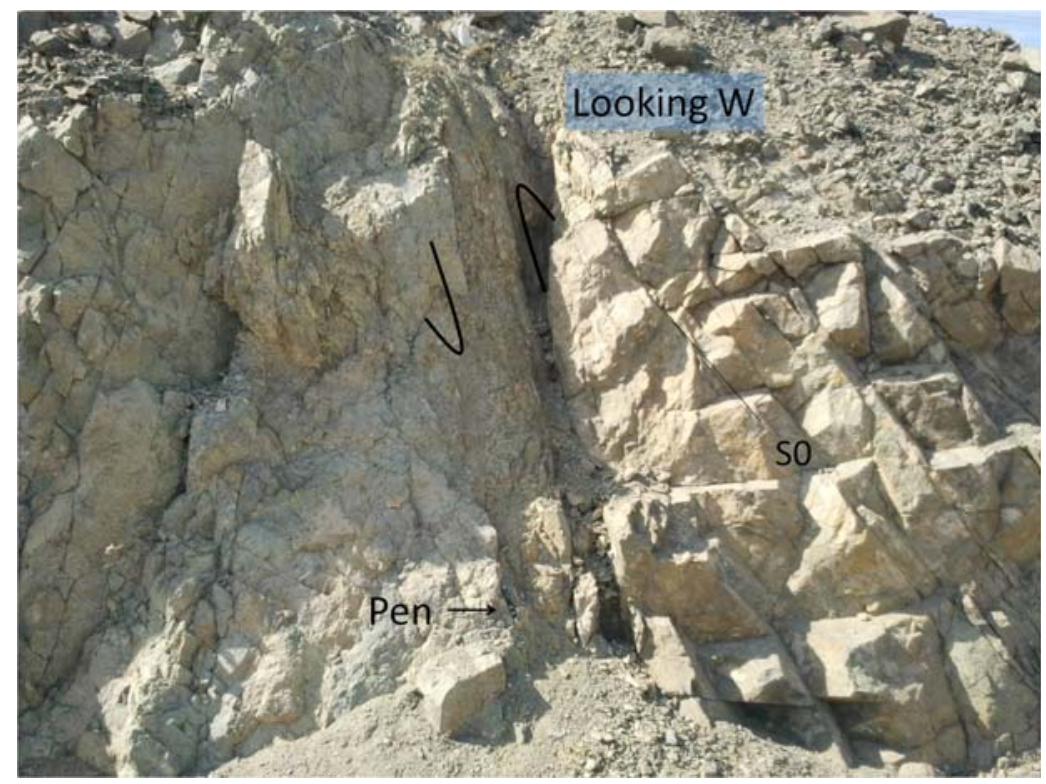

(B)

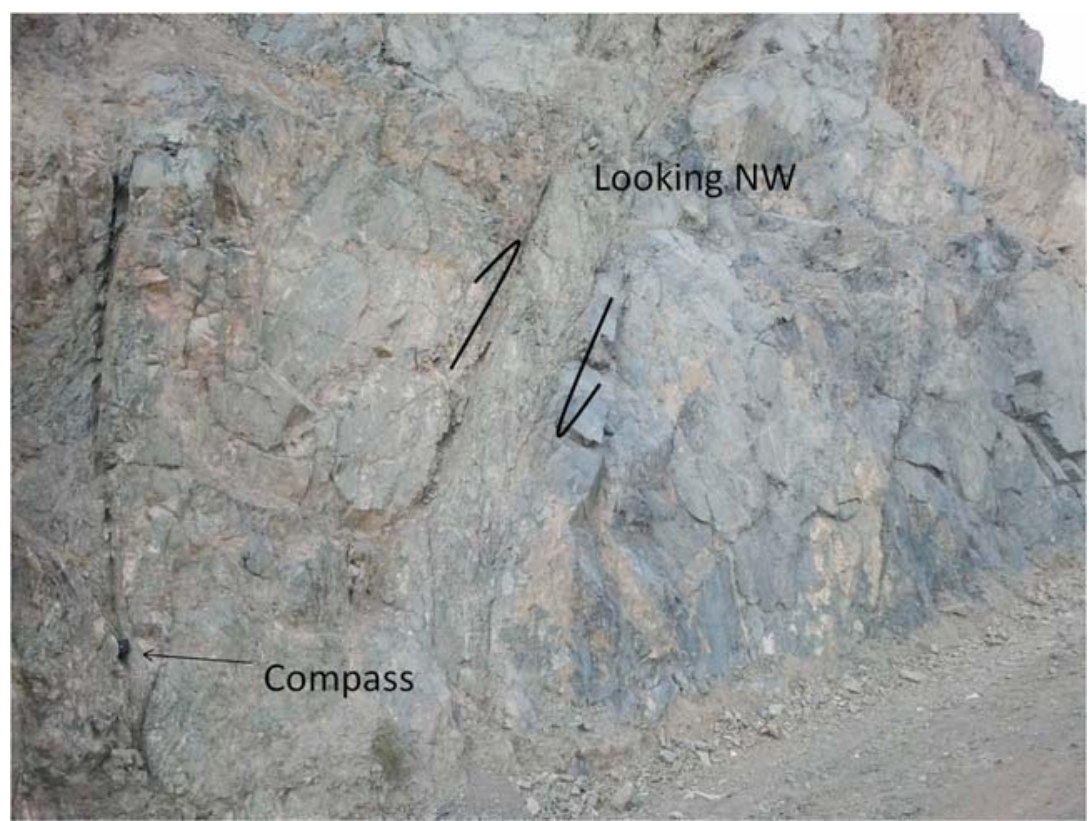

Fig. (3). Images (A, B) showing bedding surfaces $\left(S_{0}\right)$ of the Furayh Group rocks, cut by high-angle reverse faults that dip towards the north, view looking $\mathrm{W}$. 
observed in the Furayh Group, which is considered as a postamalgamation unit. These structural features are probably related to $\mathrm{D}_{3}$ deformation in the area, which faulted the Furayh Group rocks against the Birak Group and juxtaposed them against each other. Depositional contacts between these two rock units are obscured by high-angle reverse faulting, which caused low-grade metamorphism in the Furayh Group rocks, as evident from the presence of phyllosilicate minerals. According to field observations, high-angle reverse faulting has dissected granitic rocks, which intruded the Furayh Group volcanic rocks, linking their occurrences to syn-EAO activities. The granitic rocks are, therefore, considered as post-tectonic intrusions with respect to the Furayh Group rocks.

\subsection{Post-EAO Structures}

\subsubsection{Najd Strike-Slip Faults}

The NW-SE directed left-lateral strike-slip fault is observed in the area, interpreted to be a part of the NFS (Fig. 2). This fault cross-cut the $F_{2}$ folding in the north and caused deformation in the Birak Group rocks. In the southeastern part of the study area, this fault is however covered by Cenozoic basalts. This deformational event, which is considered $\mathrm{D}_{4}$ in order, produced the E-W trending F4 folding in the area as a result of rotation along the $F_{2}$ folding by Najd Faults System [11]. Features related to Najd Fault System can be observed in the study area, which bound the Al-Yutamah Dome in the northeast (Fig. 2). The $F_{4}$ folding superposition on $\mathrm{F}_{2}$ folding developed a large tectonic dome, in which older rocks of the Birak Group occur at the core,

(A)

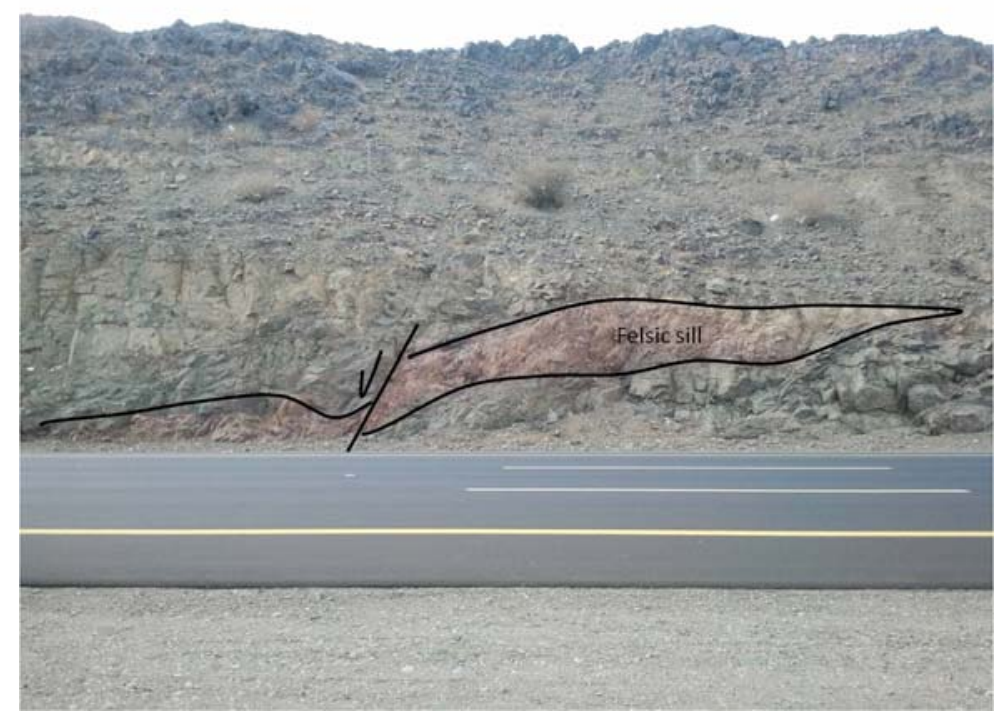

(B)

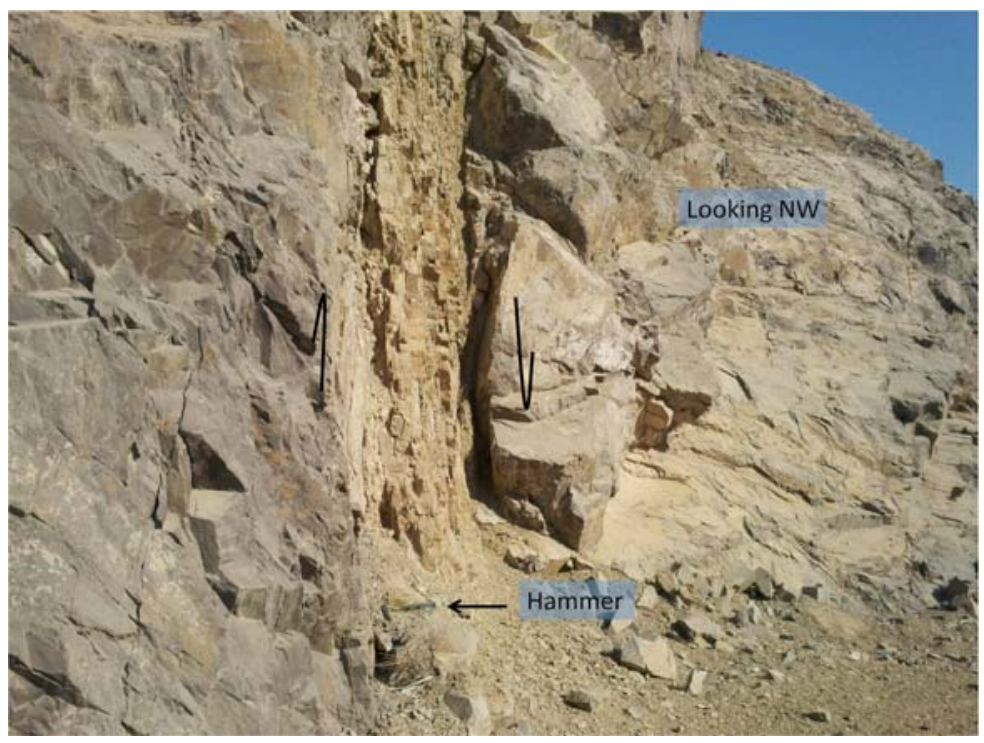

Fig. (4). A. (A) Felsic sill cut through the rocks of Birak Group, which itself is then affected by a listric fault. This sill incorporates with over-thrust fault zone in Fig. (5). Dashed lines of $5 \mathrm{~m}$ long on the asphalt road are for scale. (B) Microgranite body faulted by high-angle normal fault against rhyolite tuff of the Furayh Group, view looking W. 
(A)

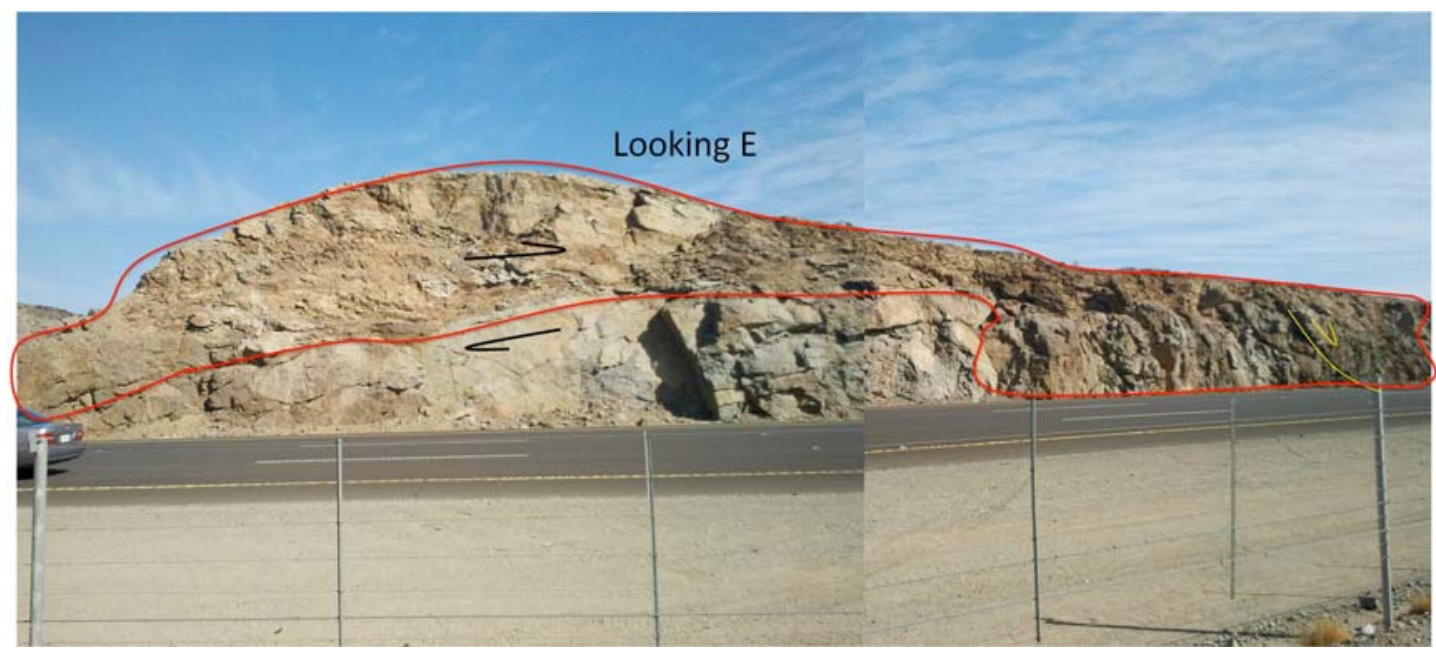

(B)

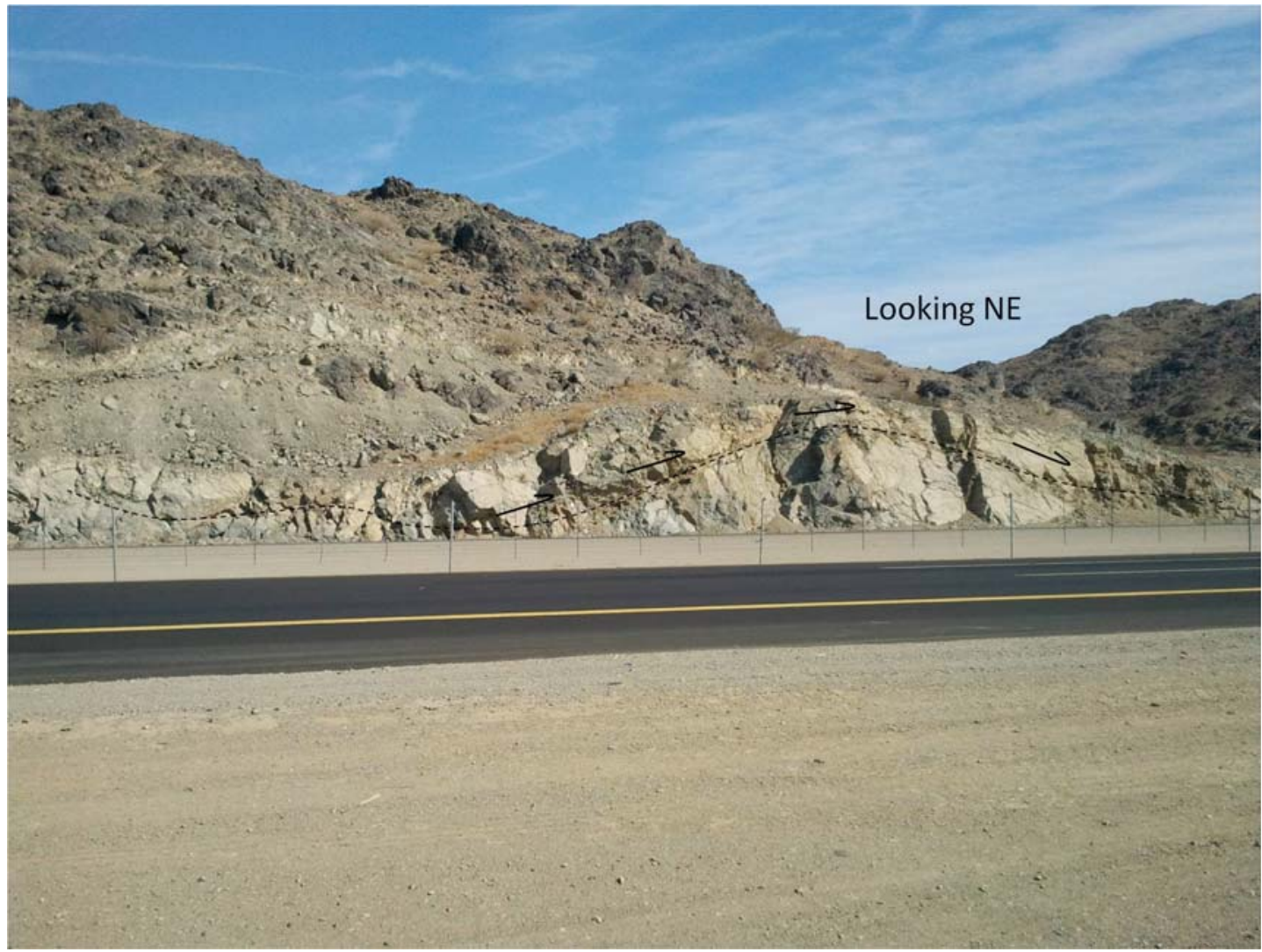

Fig. (5). (A) Over-thrust fault zone with top-to-the-south kinematics, view looking E. Note that the fault zone is cut by listric faults. (B) Single overthrust fault surface occurs to the north and south.

and the outward dipping younger rocks of Furayh Group surround them.

\subsubsection{Overthrusting Event}

Overthrusting in the area is considered as fifth deformational event $\left(D_{5}\right)$ that occurred subsequent to intrusions of the felsic dykes and sills (Fig. 4). These intrusive bodies were significantly affected by over-thrusting in the area. Kinematic analysis along the fault zone suggests that the fault is top-to-the-south and strikes generally in E-W direction (Fig. 5). It has reworked felsic and carbonate rocks of the Furayh Group. The overthrust fault extends for several hundred meters with a single surface plane (Fig. 5b) and is mainly present in the Furayh Group rocks. The successive $\mathrm{D}_{1}$ to $\mathrm{D}_{5}$ events have probably increased metamorphism in the Birak Group from greenschist to amphibolites grade [11].

\subsection{Red Sea Rifting Structures}

\subsubsection{Listric Faults Development}

The EAO formed structures are found to be generally dissected by E-W trending and southward dipping normal 
(A)

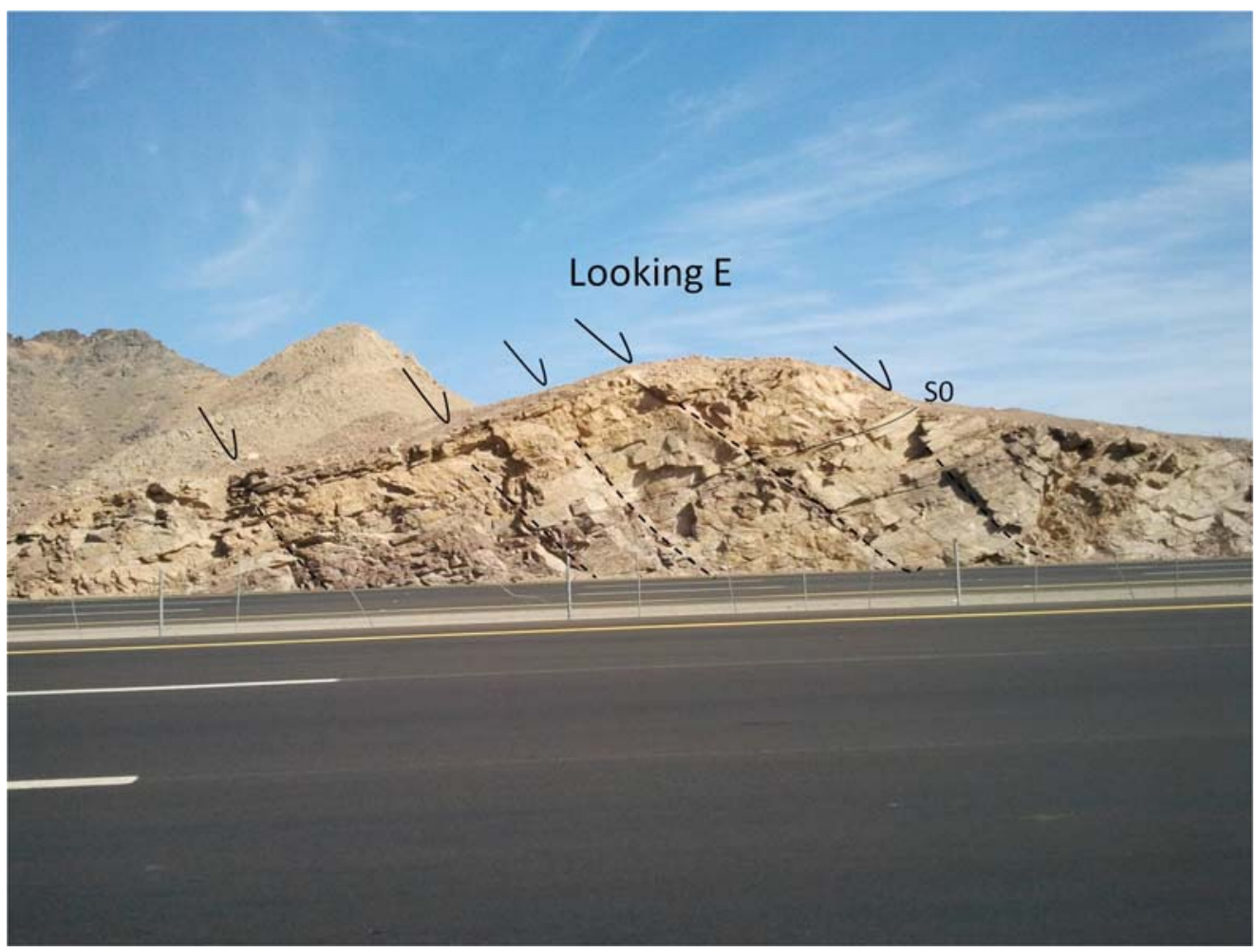

(B)

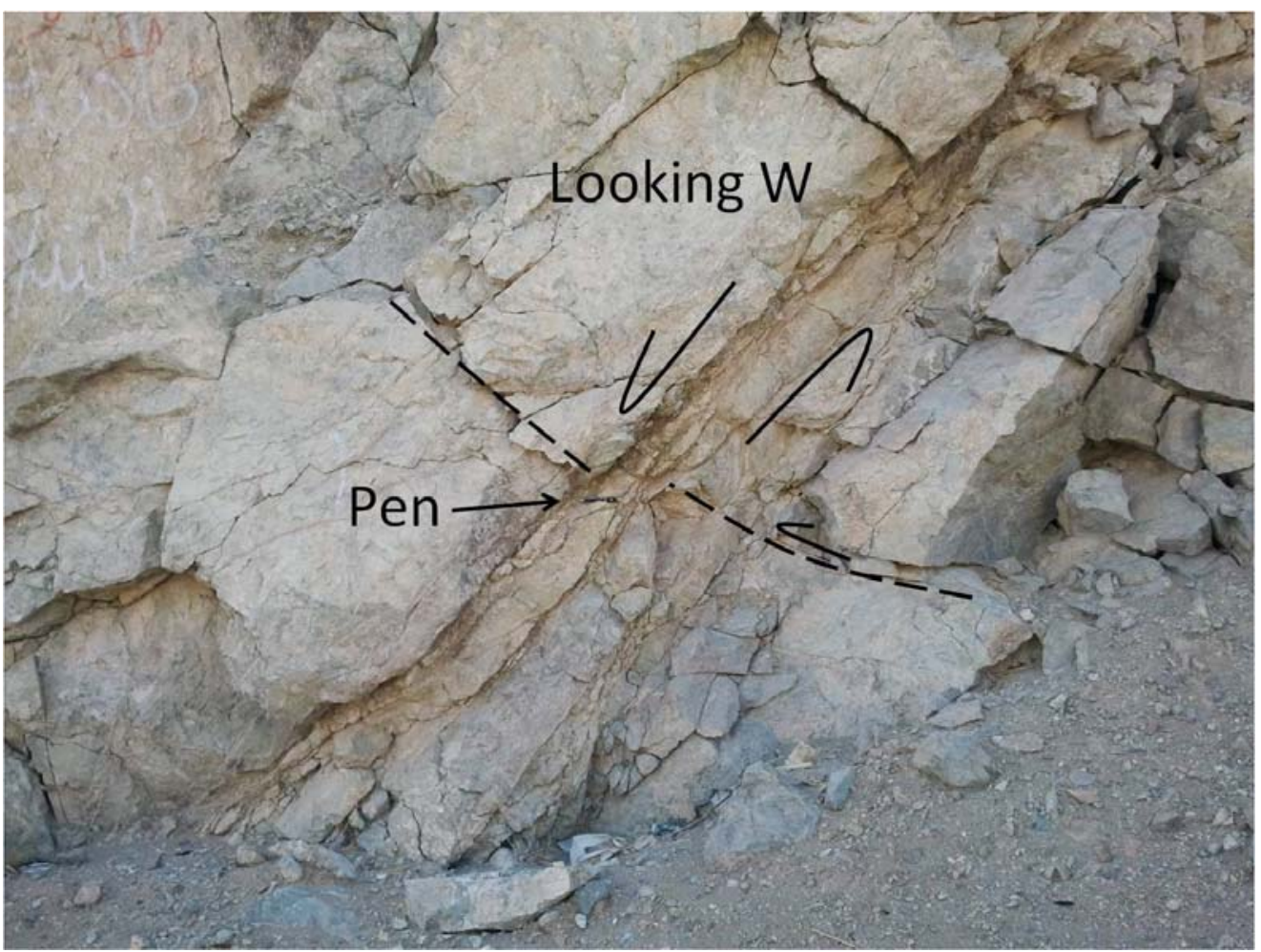

Fig. (6). (A) Listric faults cutting through the bedding of Furayh Group. (B) The listric faults can be observed in the Birak Group rocks, which cut the minor thrust faults. These phenomena are showing clear relationship between the two successive events.

faults (Fig. 6). These listric faults have probably exhumed and exposed low-grade greenschist core of the Al-Yutamah Dome during the EAO in a similar manner as the gneisses core of the Nubian Shield [24].

\subsubsection{Cenozoic High-Angle Normal Faults}

The Cenozoic extensional faults, both east-west and north-south directed, have broken the structural dome into 
several segments (Fig. 2). These faults are parts of the Red Sea rifting, which seem to have strike-slip motion. They were probably reactivated as trans-tensional faults during the final stage of Red Sea rifting.

\section{DISCUSSION}

Tectonically developed Al-Yutamah Dome, which is located in the southern part of Hijaz Terrane, is mapped by this study. Deformational features produced by folding episodes $\left(\mathrm{F}_{2}\right.$ and $\left.\mathrm{F}_{4}\right)$ and Najd faulting dominate the structural framework of the study area. These structures were developed in central part of the Arabian Shield as a result of post-amalgamation tectonic activities. The mapped $F_{2}$ and $F_{4}$ folds, located in the extreme southern part of the Hijaz Terrane, can be traced for several kilometers inward. In the study area, these folds are later on dissected by Najd Fault System as well as by Cenozoic faulting. These folding related tectonic events even affected the Ablah Group rocks of Ablah Graben (Asir Terrane) at about $500 \mathrm{~km}$ south of the study area. Theses rocks of Asir Terrane have been correlated with the Furayh Group rocks of the study area. In the Hijaz Terrane $F_{2}$ folding are more dominant in the greenschist grade metamorphic rocks. The E-W trending reverse faults have not been observed in the Asir Terrane. However, N-S trending high-angle reverse faults have been traced, which could be related to N-S directed folds in the area.

The Labunah Thrust Fault, exposed in the south of the study area, is associated with ductile structural features, such as nappe folds and mélange style [10]. However, an overthrust fault in the study area exposed the brittle deformation, which has incorporated the metamorphosed carbonate and felsic rocks of the Furayh Group. The Labunah Thrust Fault was probably developed in a different environment, may be much deeper than the environment of the over-thrust faults in the study area. The Labunah Thrust Fault was probably developed as a result of oceanic crust subduction beneath the continental crust. On the other hand, faults in the study area are younger in age due to their formation at the time of continent-continent collision. It can thus be said that the Alyutamah Over-thrust fault is most likely related to the NFS development due to its cross-cut relationship with the late wrench activities and with the post-tectonic granitic intrusions.

\section{CONCLUSION}

The Birak Group of rocks in the study area is affected by low-grade greenschist metamorphism during the 783-764 Ma interval, when the Asir Terrane was probably subducting beneath the Hijaz Terrane. The rock units of the Birak Group may have developed $S_{1}$ cleavages during the 783-764 Ma interval. Rock units related to Furayh Group were deposited over the Birak Group rocks in post-amalgamation basins, and were not affected by structures related to $\mathrm{D}_{1}$ deformation ( $S_{1}$ cleavages). Following their deposition, the Furayh Group rocks were folded and faulted against the Birak Group rocks during the EAO tectonisms $\left(\mathrm{D}_{2}-\mathrm{D}_{3}\right)$. The pre- and syn-EAO $\left(D_{1}-D_{3}\right)$ structures development were followed by strike-slip faulting $\left(\mathrm{D}_{4}\right)$ that produced $\mathrm{F}_{4}$ folding and formed a large dome structure. Activities along the NFS produced $\mathrm{F}_{4}$ folding by rotating $F_{2}$ folds in the area. The easterly and westerly dipping limbs of this regional dome can be observed along the transacted highway. Low greenschist grade metamorphic rocks constitute the core of the dome, forming it as a complex anticlinorium. Minor N-S trending $\mathrm{F}_{2}$ folds can also be observed in some areas, particularly in central part of the dome. Greenschist grade metamorphism increased into amphibolites grade metamorphism, which may be due to successive tectonic activities. Over-thrust faulting in the study area (related to $\mathrm{D}_{5}$ deformation) probably occurred subsequent to movement along the NFS.

\section{CONFLICT OF INTEREST}

The authors confirm that this article content has no conflict of interest.

\section{ACKNOWLEDGMENTS}

The author is grateful to anonymous reviewers for their suggestions and comments that improved the text significantly. The author is also grateful to chief editor for his support. The author is also in dept to Prof. Haider Zaman and Prof. Zakaria Hamimi for their help, suggestions and comments that enhanced the manuscript.

\section{REFERENCES}

[1] Hargrove US, Stern RJ, Kimura J, Manton WI, Johnson PR. How juvenile is the Arabia-Nubian Shield? Evidence from Nd isotopes and pre-Neoproterozoic inherited zircon in the Bi'r Umq suture zone. Saudi Arabia. Earth Planeta Sci Lett 2006; 252: 306-28.

[2] Stoeser DB, Camp VE. Pan-African microplate accretion of the Arabian Shield. Geol Soc Am Bull 1985; 96: 817-26.

[3] Genna A, Guerrot C, Deschamps Y, Nehlig P, Shanti M. Les formations Ablah d'Arabie Saoudite (datation et implication géologique). Earth Planet Sci Lett 1999; 329: 661-67.

[4] Blasband B, White S, Brooijmans P, De Boorder H, Visser W. Late Proterozoic extensional collapse in the Arabian-Nubian Shield. J Geol Soc Lond 2000; 157(3): 615-28.

[5] Johnson P. Post-amalgamation basins of the NE Arabian shield and implications for Neoproterozic III tectonism in the northern East African orogen. Precambrian Res 2003; 123: 321-37.

[6] Stoeser DB, Frost CD. Nd, Pb, Sr and $\mathrm{O}$ isotopic characterization of Saudi Arabian Shield terranes. Chem Geol 2006; 226: 163-88.

[7] Johnson PR, Kattan FH. Lithostratigraphic revision in the Arabian Shield: The impacts of geochronology and tectonic analysis. Arab J Sci Eng 2008; 33(1): 3-16.

[8] Bamousa A. Infracambrian superimposed tectonics in the late Proterozoic units of Mount Ablah area, southern Asir Terrane, Arabian Shield Saudi Arabia. Arab J Geosci 2013; 6: 2035-44.

[9] Stern RJ, Johnson P. Continental lithosphere of the Arabian Plate: A geologic, petrologic, and geophysical synthesis. Earth-Sci Rev 2010; 101: 29-67.

[10] Ramsay CR. Geologic Map of the Rabigh quadrangle, sheet 22D, Kingdom of Saudi Arabia. Saudi Arabian Deputy Ministry For Mineral Resources 1986; GM 84C, scale 1:250 000, with text, p. 49.

[11] Camp VE. Geologic Map of the Umm Al Birak quadrangle, sheet 23D, Kingdom of Saudi Arabia. Saudi Arabian Deputy Ministry For Mineral Resources 1986; GM 87C, scale 1:250 000, with text, p. 40 .

[12] Stern RJ. Arc assembly and continental collision in the Neoproterozoic East African Orogen: implication for the consolidation of Gondwanaland. Annu Rev Earth Planetary Sci 1994; 22: 319-51.

[13] Abdelsalam MG, Stern RJ. Sutures and shear zones in the ArabianNubian Shield. J Afr Earth Sci 1996; 23: 289-310.

[14] Johnson PR, Woldehaimanot B. Development of the ArabianNubian Shield: Perspectives on accretion and deformation in the northern East African Orogen and assembly of Gondwana. In: Yoshida M, Dasgupta S, Windley B, Eds. Proterozoic East Gondwana: Supercontinent Assembly and Breakup. Spe Pub GeolSoc Lond 2003; 206: 289-325.

[15] Abdelsalam MG. Quantifying 3D post-accretionary tectonic strain in the Arabian-Nubian Shield: Superimposition of the Oko Shear 
Zone on the Nakasib Suture, Red Sea Hills, Sudan. J Afr Earth Sci 2010; 56: 167-78.

[16] Abdelsalam MG. The Oko Shear Zone, Sudan: post-accretionary deformation in the Arabian-Nubian Shield. J Geol Soc Lond 1994; 151: 767-76.

[17] Stern RJ. The Najd Fault System, Saudi Arabia and Egypt: A Late Precambrian rift-related transform system? Tectonics 1985; 4(5): 497-511.

[18] Moore JM. Tectonics of the Najd Transcurrent Fault System, Saudi Arabia. J Geol Soc Lond 1979; 136: 441-54.

[19] Kaliwoda M, Altherr R, Meyer HP. Composition and thermal evolution of the lithospheric mantle beneath the Harrat Uwayrid, eastern flank of the Red Sea rift (Saudi Arabia). Lithos 2007; 99: 105-20.

[20] Chang SJ, Van der Lee S. Mantle plumes and associated flow beneath Arabia and East Africa. Earth Planet Sci Lett 2011; 302: 448-54.
[21] Camp VE, Roobol MJ. The Arabian continental alkali basalt province. Part I. Evolution of Harrat Rahat, Kingdom of Saudi Arabia. Geol Soc Am Bull 1989; 101: 7-95.

[22] Moufti MRH, Hashad MH. Volcanic hazards assessment of Saudi Arabian Harrats: geochemical and isotopic studies of selected areas of active Makkah- Madinah-Nafud (MMN) volcanic rocks. King Abdlaziz City for Science and Technology, Riyadh: Saudi Arabia Final Project Report (LGP-5-27) 2005.

[23] Al-Amri AM, Fnais MS, Kamal A, Mogren S, Al-Dabbagh M Geochronological dating and stratigraphic sequences of Harrat Lunayyir, NW Saudi Arabia. Int J Phys Sci 2012; 7(20): 2791-28.

[24] Andresen A, Augland LE, Boghdady GY, et al. Structural constraints on the evolution of the Meatiq Gneiss Dome (Egypt), East-African Orogen. J Afr Earth Sci 2010; 57: 413-42.

(c) Abdullah O. Bamousa; Licensee Bentham Open.

This is an open access article licensed under the terms of the Creative Commons Attribution Non-Commercial License (http://creativecommons.org/licenses/by$\mathrm{nc} / 3.0 /$ ) which permits unrestricted, non-commercial use, distribution and reproduction in any medium, provided the work is properly cited. 